\title{
Locally Advanced Leiomyosarcoma
}

National Cancer Institute

\section{Source}

National Cancer Institute. Locally Advanced Leiomyosarcoma. NCI Thesaurus. Code C160917.

A leiomyosarcoma that has spread from its original site of growth to nearby tissues or lymph nodes. 